Paweł Kowal

\title{
W CIENIU GIEDROYCIA. DYSKUSJE O POLSKIEJ POLITYCE WSCHODNIEJ PO 1989 ROKU
}

Z punktu widzenia badania historii współczesnej polskiej myśli politycznej kwestia polityki wschodniej jest jednym z najważniejszych zagadnień. Obok problemów takich jak historyczne rozliczenia z przeszłością, lustracja czy kształt ustroju III Rzeczypospolitej polityka wschodnia Polski jest stałym elementem debaty politycznej po 1989 r. Większość z tych dyskusji znalazła swoje opracowanie $\mathrm{w}$ postaci analiz z punktu widzenia rozwoju polskiej myśli politycznej. Tymczasem, wyjąwszy opisy i analizy kwestii polityki wschodniej w programach partii politycznych czy rządu ${ }^{1}$, nie ma syntetycznych opracowań naukowych czy analitycznych dotyczących współczesnej myśli wschodniej w ciągu ostatnich trzydziestu lat obejmujących publicystykę.

Poniższe opracowanie stanowi przyczynek do tych badań dokonany w oparciu o następujące założenia: jako materiał źródłowy do opracowania zostały potraktowane wyłączenie tradycyjne teksty publicystyczne stanowiące całościowe wypowiedzi, które pozwalają na analizowanie całościowego poglądu autorów i śledzenie zmian ich punktu widzenia w kontekście wydarzeń politycznych. Polska polityka wschodnia w latach 1989-1991 ukształtowała się w oparciu o linię polityczną Kultury, czyli założenia poczynione przez duet Jerzego Giedroycia i Juliusza Mieroszewskiego, za kluczowy zaś moment jej krystalizacji

${ }^{1}$ Por. J. Strzelczyk (2002): Ucieczka ze Wschodu. Rosja w polskiej polityce 1989-1993, Warszawa; A.J. Madera (2003): Polska polityka zagraniczna. Europa Środkowo-Wschodnia 1989-2003, Rzeszów; P. Malewicz (2008): Polska polityka wschodnia w latach 1989-1991, Toruń; P. Żurawski vel Grajewski (2016): Polska polityka wschodnia 1989-2015. Wymiar narodowy i unijny, Kraków, A. Krawcewicz (2018): Polityka wschodnia w koncepcjach partii politycznych w III Rzeczypospolitej Polskiej. Wybrane aspekty: stosunki międzynarodowe, polityka historyczna, gospodarka i integracja europej$s k a$, Infort Editions. 
uznać należy 2 grudnia 1991 r., kiedy Polska jako pierwsze państwo na świecie uznała suwerenność Ukrainy ${ }^{2}$.

Ze względu na ograniczony zakres opracowania zostały wzięte pod uwagę debaty toczone wokół założeń doktryny Jerzego Giedroycia, prometeizmu, tradycji i solidarności - które zresztą dominują wśród tekstów publicystycznych i manifestów poświęconych polskiej polityce wschodniej w III Rzeczypospolitej. Badacza zaskakuje duża liczba tekstów, został więc dokonany wybór tych $\mathrm{z}$ artykułów, które w największym stopniu były komentowane lub nadawały ton prowadzonej debacie. Układają się one w kilka faz, w których prowadzona była debata o polskiej polityce wschodniej w kontekście linii politycznej Giedroycia i Kultury (przede wszystkim 2000-2001, 2008-2009, 2010). Dyskusje te były każdorazowo powiązane z konkretnymi wydarzeniami w polskiej polityce zagranicznej, w tym szczególnie wschodniej, w dwóch wypadkach zakończyły się otwartymi debatami, w których mieli okazję spotkać się i kontynuować dyskusję polemiści.

Dyskusje toczyły się na łamach kilku czasopism - jednak głównymi forami były: Tygodnik Powszechny, Rzeczpospolita i Nowa Europa Wschodnia. Wszystkie trwały jednocześnie na kilku poziomach: krytycznej interpretacji idei Giedroycia, odniesień do aktualnej polityki wschodniej Polski i doraźnych polemik politycznych. Powoduje to, że w ramach niniejszego tekstu nie sposób dokonać całościowej analizy tego materiału - można jednak wskazać główne wątki dyskusji, ich kontekst historyczny i zaproponować lekturę wybranego materiału źródłowego.

\section{Archeologia idei. Jak powstała polityka wschodnia III Rzeczypospolitej?}

Program polityki wschodniej III Rzeczypospolitej, który ukształtował się w opozycji do środowiska władzy w PRL, wyrósł w oparciu o linię polityczną Kultury i miał charakter neoprometejski ${ }^{3}$. Powstawał on w trzech etapach: okres

2 Por. P. Kowal (2018): Testament Prometeusza. Źródła polityki wschodniej III Rzeczypospolitej, Warszawa-Wojnowice, s. 651-654.

3 Definicja prometeizmu wedle badacza P. Libery: „«Prometeizm» to w ogólnym pojęciu idea buntu przeciwko potęgom krępującym wolność myśli i ograniczającym wolność narodów i człowieka. W pierwszej połowie XX wieku termin ten oznaczał polityczną współpracę II Rzeczypospolitej z nierosyjskimi ludami i narodami Rosji skierowaną przeciwko carskiemu, a później sowieckiemu imperium. Bezpośrednie autorstwo tej koncepcji przypisywano Józefowi Piłsudskiemu, który w 1904 roku 
od 1952 r., czyli od publikacji w Kulturze Listu ks. Majewskiego, poprzez kluczowe teksty Juliusza Mieroszewskiego Polska Ostpolitik oraz Rosyjski kompleks Polski i obszar ULB do 1978 r., czyli do wyboru Karola Wojtyły na papieża ${ }^{4}$.

Drugi etap to czas od 1978 r. do 1981 r., czyli do przyjęcia przez I Zjazd NSZZ „Solidarność” Postania do ludzi pracy... Od 1977 r. Zbigniew Brzeziński był doradcą ds. bezpieczeństwa prezydenta USA Jimmy'ego Cartera, rok potem Polak został papieżem. Współczesne badania historyczne pozwalają postawić tezę, że znaczenie Jana Pawła II i Zbigniewa Brzezińskiego dla rozbicia ZSRS i bloku sowieckiego było dużo większe, niż się zwyczajowo uważa.

Jednocześnie pod koniec lat 70 . XX wieku tematyka wschodnia znalazła się w polskich wydawnictwach podziemnych w kraju i pojawily się, choć ograniczone, symptomy zmiany podejścia do kwestii polityki wschodniej w środowisku Rządu Rzeczypospolitej Polskiej w Londynie. Punktem zwrotnym był I Zjazd „Solidarności”. Uchwalone podczas jego obrad Postanie do ludzi pracy...

w memoriale do rządu japońskiego jako cel polityczny Polski stawiał słowa, które również można uznać za pierwszą definicję prometeizmu: «rozbicie państwa rosyjskiego na główne części składowe i usamowolnienie przemocą wcielonych w skład Imperium krajów»”. Ramy chronologiczne funkcjonowania ruchu prometejskiego w sensie organizacyjnym, za którymi optuje P. Libera, to lata po pokoju ryskim (1921) do II wojny światowej (por. P. Libera (2013): Wstęp, [w: ] tegoż, II Rzeczpospolita wobec ruchu prometejskiego, Warszawa, s. 15 i 17-18). Oprócz ruchu prometejskiego w ujęciu P. Libery i idei (myśli) prometejskiej można jeszcze mówić w moim przekonaniu o polityce prometejskiej - na przykład ze strony Polski i innych państw zachodnich w odniesieniu do Ukrainy w okresie pomarańczowej rewolucji. Nie będę rozwijał niniejszego wątku, sygnalizuję jedynie, że można mówić o trzech oddzielnych pojęciach: ruchu, idei i polityce prometejskiej, które mają pole wspólne, ale nie są tożsame (por. P. Libera, Wstęp, op. cit., s. 17-18). Pojęcie neoprometeizmu wprowadzam w związku z ustaleniami badaczy problemu, m.in. Jana Skórzyńskiego i Przemysława Żurawskiego vel Grajewskiego, szczegółowo problematykę te omówiłem w swojej ostatnio opublikowanej pracy (por. P. Kowal, Testament Prometeusza..., s. 99).

4 Por.: P. Kowal, Testament Prometeusza..., s. 208-215. Duże znaczenie dla tych konstatacji mają nowe informacje na temat relacji politycznych na linii Z. Brzeziński-Jan Paweł II, a także nowe prace polskich i amerykańskich historyków wskazujące na polityczną rolę USA w transformacji Europy Środkowej i Wschodniej [G.F. Domber (2014): Empowering Revolution: America, Poland, and the End of the Cold War, University of North Carolina Press, Chapel Hill; J. Tyszkiewicz (2015): Rozbijanie monolitu. Polityka Stanów Zjednoczonych wobec Polski 1945-1988, Warszawa; P. Zyzak (2016): Efekt domina. Czy Ameryka obaliła komunizm w Polsce?, t. 1-2, Warszawa; S.G. Jones (2018): A covert action. Reagan, The CIA, and the Cold War struggle in Poland, W.W. Norton \& Company, New York]. 
stanowiło przełomowy etap $\mathrm{w}$ formułowaniu programu polityki wschodniej, ponieważ dawało programowi powstałemu w środowisku Kultury mocną legitymizację społeczną w postaci oficjalnej uchwały największej niezależnej organizacji w kraju. Nie był to już zatem program elity intelektualnej, ale mógł być uważany za program narodowy 5 .

Trzeci okres formowania się nowego programu polskiej polityki wschodniej po II wojnie światowej to czas wielkich dyskusji o polityce wschodniej w solidarnościowym podziemiu w latach 1981-1989. Za symboliczny koniec tego etapu uznać można program Obywatelskiego Klubu Parlamentarnego przygotowany jeszcze na wybory $1989 \mathrm{r}^{6}{ }^{6}$ Swego rodzaju rozwinięciem i logiczną kontynuacją Postania do ludzi pracy... z 1981 r. był program Komitetu Obywatelskiego (KO) w 1989 r. Program Komitetu Obywatelskiego w odniesieniu do polityki wschodniej w 1989 r. w swej wymowie wręcz przypominał Postanie do ludzi pracy... Jego cechą byly umiar i samoograniczenie się w formułowaniu postulatów wobec Sowietów, co i tak było nie do przyjęcia dla sowieckiego przywództwa. Takie podejście - taktycznie dalekie od radykalizmu - cieszyło się poparciem najpoważniejszego strategicznego zagranicznego sojusznika polskiej opozycji, czyli USA.

W pewnym uproszczeniu Stany Zjednoczone miały w tej koncepcji zapewnić bezpieczeństwo i parasol ochronny dla reform w Polsce i innych państwach regionu w zamian za ograniczanie ewentualnych kłopotów, które by dodatkowo je angażowały w regionie, a wynikały z potencjalnych konfliktów na wschodzie Europy (stąd przykładowo akceptacja wyboru Wojciecha Jaruzelskiego na prezydenta jako element zapewnienia politycznej stabilizacji w regionie). Sens programu KO w części wschodniej trzeba więc odczytywać we właściwym kontekście i mieć do tego dokumentu podejście inne niż do publicystyki w podziemnych czasopismach. Miał on charakter polityczny, toteż podlegał ograniczeniom typowym dla tego rodzaju tekstów.

W ciągu niecałych ośmiu lat po wprowadzeniu stanu wojennego przez prasę opozycyjną przetoczyła się wielka dyskusja o polityce wschodniej. Biorąc pod uwagę niekorzystne okoliczności, w jakich toczyły się te dyskusje, trzeba je uznać za swoisty fenomen bogactwa idei, pomysłów i sporów. Na początku neoprometejski program wschodni opozycji stanowił przede wszystkim recepcję idei Kultury ${ }^{7}$, potem także próbę odpowiedzi na aktualne trendy w sowietologii

5 Por.: P. Kowal, Testament Prometeusza ... , s. 215-219.

6 Por.: ibid., s. 265-292.

7 Kwestia ta - recepcji pisma w kraju, jego sposobu oddziaływania - wciąż potrzebuje szczegółowych badań, które otwiera cytowana praca Iwony Hofman pt. „Kultura” i jej odbiór $w$ Polsce. W sensie badań prasoznawczych pozostaje nie do końca opisanym fenomenem, że Kultura jako jedno z emigracyjnych pism zyskała tak wielkie możli- 
na świecie, dopiero z czasem pojawiały się w myśli politycznej środowisk opozycyjnych wypracowane w tych gremiach pomysty programowe.

Debata o polityce wschodniej, która toczyła się w podziemiu w latach po wprowadzeniu stanu wojennego, miała oprócz swej dużej skali jeszcze jeden wymiar - pokazywała, że wchodzące w życie publiczne kolejne pokolenia działaczy podziemia chcą w sprawach polityki wschodniej mówić swoim głosem, choćby bazując na dorobku Kultury czy sowietologii na świecie. Pojawiało się też coraz mocniejsze przekonanie, że w razie rozpadu ZSRS Polacy mają do zaoferowania unikalną wiedzę na temat realnej sytuacji na Wschodzie, procesów społecznych w ZSRS. Wyrazem tych trendów były nie tylko artykuly w czasopismach podziemnych, lecz także działania Instytutu Europy Wschodniej czy już w okresie przełomu politycznego Zespołu Badań Europy Wschodniej ${ }^{8}$.

Po przyjęciu Postania do ludzi pracy... z września 1981 r. główne nurty dyskusji na tematy wschodnie można $\mathrm{w}$ pewnym uproszczeniu przedstawić jako spór w ramach szerokiego obozu wyznającego wartości prometejskie. W takim ujęciu był to spór między tymi, którzy za Mieroszewskim liczyli równolegle na rozpad imperium wedle kryterium narodowego i demokratyzację samej Rosji (nazwijmy ich umiarkowanymi prometeistami), a tymi, którzy jako jedyny cel stawiali wsparcie na rzecz rozczłonkowania imperium bez formowania nadziei co do możliwości zmiany systemu politycznego w Rosji (można ich nazwać integralnymi prometeistami lub maksymalistami).

W tle tej dyskusji toczyła się debata, czy do zrealizowania polskich planów politycznych odzyskania niepodległości wystarczy tylko zmiana ustroju Rosji (czy inna zmiana polityczna w tym kraju), czy też konieczny jest calkowity rozpad systemu imperialnego powstałego wokół ZSRS. Pozostawało jeszcze oczywiście pytanie o nadzieje związane z pieriestrojką w ZSRS. Oba nurty się przenikały i miały wiele wspólnego (związek polityki wschodniej z zagadnieniem niepodległości Polski, wyrzeczenie się rewindykacji granicznych, wsparcie dla niepodległości sąsiadów, nacisk na prawa mniejszości narodowych itd.). Po kilku dekadach różnice te nie wydają się tak ostre, ale ówczesny podział pomaga zrozumieć późniejsze spory o polską politykę wschodnią zarówno w aspekcie personalnym, generacyjnym (maksymaliści reprezentowali z reguły młodsze pokolenie), jak i programowym.

Nurty wyodrębnione w tamtym okresie pokrywały się częściowo z podziałami politycznymi występującymiw III Rzeczypospolitej. Wszelako wśrodowiskach

wości politycznego oddziaływania w kraju. Było to przecież pismo, z którym zarówno zwolennicy jego linii, jak i przeciwnicy wiązali wielkie nadzieje na sformułowanie polityki wschodniej III Rzeczypospolitej.

${ }^{8}$ P. Kowal, Testament Prometeusza..., s. 225-226. 
opozycji zainteresowanych polityką wschodnią, zarówno bliższych poglądom prawicowym, jak i lewicowym, dominował neoprometeizm w różnych wariantach. Rozumieć można przez to postawę antyimperialną, antykomunistyczną i otwartą na pomoc w uzyskaniu niepodległości przez poszczególne państwa i narody znajdujące się w składzie ZSRS. Paradoks polskiego podejścia do polityki wschodniej polegał na tym, że postawa neoprometejska nie była początkowo podzielana przez pierwszego ministra sprawa zagranicznych III Rzeczypospolitej Krzysztofa Skubiszewskiego.

\section{Spór o taktykę wschodnią gabinetu Tadeusza Mazowieckiego (1989-1990)}

Za tekst otwierający współczesne debaty o polityce wschodniej toczone w duchu linii politycznej Jerzego Giedroycia można uznać artykuł pt. Nasza polityka wschodnia Andrzeja Friszkego, który został zamieszczony w pierwszym numerze oficjalnie wydawanego Tygodnika Solidarność z 3 czerwca 1989 r. Był to pierwszy po wprowadzeniu stanu wojennego artykuł programowy o polityce wschodniej zamieszczony w reprezentatywnym piśmie „Solidarności” wydawanym bez cenzury. W tym tekście Friszke, odnosząc się do poglądów panujących w kręgach opozycji, proponował odcięcie się (co oczywiste) zarówno od zdecydowanych zwolenników współpracy z Rosją, jak i od tych, którzy stawiali przede wszystkim na rozczłonkowanie Związku Sowieckiego.

Charakterystyczne w tym tekście są typowe dla linii politycznej Kultury historyczne interpretacje relacji Polaków ze wschodnimi sąsiadami. Jednocześnie tekst stanowil manifest ostrożności w polityce wschodniej. Autor podkreślał pozytywne nastawienie do ewolucji stosunków w ZSRS $w$ kierunku demokracji. Łączył podejście do kwestii mniejszości narodowych w Polsce $\mathrm{z}$ zainteresowaniem losem sąsiadów - byłych sowieckich republik. $\mathrm{Z}$ artykułu redaktora działu historycznego Tygodnika Solidarność przebijała świadomość potencjalnych problemów Polski z najbliższymi sąsiadami na tle sporów historycznych, dlatego też zwracał uwagę na konieczność rewizji przez Ukraińców ich podejścia do nacjonalistycznej tradycji - był to zresztą po polskiej stronie postulat w tamtym czasie częsty - stanowil przykładowo oś wystąpienia Adama Michnika podczas zjazdu ruchu w Kijowie we wrześniu 1989 r. ${ }^{10}$

9 A. Friszke (1989): Nasza polityka wschodnia, Tygodnik Solidarność, nr 1, s. 9.

10 O.W. Garan (1993): Ubiti Drakona. Z istorii Ruchu ta nowich partii Ukrainy, Libid, Kijev, s. 53. 
Andrzej Friszke proponował, by w relacjach z sąsiadami postawić na umiarkowane pozytywistyczne cele, uczyć się wzajemnie historii, poznawać kulturę. Na zmiany w ZSRS należało jego zdaniem reagować organiczną pracą u podstaw. Kończył znamienną dla paradygmatu polityki wschodniej Kultury deklaracją: Nie perspektywa rewizji granic i nawrotu sporów terytorialnych powinna być naszym celem. Powinniśmy natomiast dążý do tego, aby istniejace granice staty się granicami otwartymi ${ }^{11}$.

Po kilku tygodniach na łamach pisma ukazała się zasadnicza polemika z tekstem. Jerzy Łukaszewski dowodzil, że oceny Friszkego skierowane pod adresem Ukraińców w kontekście spraw historycznych są zbyt surowe i stereotypowe. Postulował, by zacząć polską politykę wschodnią od wypełnienia zobowiązań KBWE wobec mniejszości ${ }^{12}$.

Kwestia łączenia problemu mniejszości narodowych z polityką wschodnią była rozpowszechnionym podejściem w kręgach „Solidarności”. Chodziło o swego rodzaju pozytywne warunkowanie relacji z partnerami na Wschodzie poprzez demonstrowanie pozytywnego stosunku odradzającego się państwa polskiego do mniejszości narodowych. Sprawa ta miała kilka różnych kontekstów: nawiązania do historii wielonarodowej I Rzeczypospolitej, nawiązywanie do uchwały I Zjazdu NSZZ „Solidarność” z 7 października 1981 r. $^{13}$, demonstrowanie, że nowe polskie elity zdecydowane są wypełnić zobowiązania międzynarodowe, jeśli chodzi o mniejszości narodowe i, rzecz jasna, zwalczanie stereotypu, że historycznie rzecz ujmując relacje z mniejszościami narodowymi stanowily swego rodzaju strukturalny problem Polski. Zwracający uwagę na ten aspekt, Łukaszewski posiłkował się doświadczeniem w instytucjach międzynarodowych i rozumiał znaczenie podnoszonego problemu.

Dyskusja o polityce wschodniej była w zasadzie stałym elementem repertuaru Tygodnika Solidarność ${ }^{4}$. Szczególnie z tekstu Andrzeja Friszkego wynika kilka istotnych wniosków, które konstytuowały kolejne debaty o polityce wschodniej w III Rzeczypospolitej. Po pierwsze pojęcie polityki wschodniej w odniesieniu do odrodzonego państwa polskiego było już wówczas ugruntowane i zrozumiałe. Po drugie tematyka polityki wschodniej była od początku

11 A. Friszke, Nasza polityka wschodnia..., s. 9.

12 J. Łukaszewski (1989): Z kim rozmawiać na Wschodzie, Tygodnik Solidarność, nr 6, s. 11.

13 NSZZ „Solidarność”, Uchwała w sprawie mniejszości narodowych, w: Nie jesteśmy ukrainofilami..., s. 354.

14 Por. W. Giełżyński (1990): Wariant rezerwowy: Europa Środkowa, Tygodnik Solidarność, nr 10. 
integralnym elementem dyskusji o kształcie odrodzonego państwa, po trzecie - odnoszono się przede wszystkim do dorobku Kultury i „Solidarności”.

Dorobek intelektualny podziemia antykomunistycznego był przywoływany rzadko, prawdopodobnie traktowany był przede wszystkim jako pewien etap w rozwoju linii politycznej Giedroycia i Mieroszewskiego. Zaskakujące, w jak małym stopniu podkreślano wówczas rolę Jana Pawła II w ukształtowaniu polityki wschodniej - dzisiejsze ustalenia nakazują widzieć to inaczej, szczególnie w kontekście analizy wystąpień Jana Pawła II podczas wizyty w Polsce w 1991 r.: w Przemyślu, Lubaczowie, Łomży i Białymstoku. Początkowe spory o detale polskiej polityki wschodniej, jak ten Łukaszewskiego z Friszkem, po roku zamieniły się w bardzo już ostre jak na tamte czasy polityczne polemiki.

Pierwszy rok urzędowania Krzysztofa Skubiszewskiego jako ministra spraw zagranicznych był okresem, kiedy udało się określić najważniejsze problemy w polityce zagranicznej (konieczność traktatowego uregulowania relacji z sąsiadami, w tym szczególnie z Niemcami, relacje z instytucjami zachodnimi EWG i NATO), także w polityce wschodniej. Z punktu widzenia polityki wschodniej centralnymi kwestiami były: wyprowadzenie wojsk sowieckich z Polski jako bazowy warunek uzyskania niepodległości kraju, charakter relacji z Rosją i pozostałymi państwami, które wyłaniały się z ZSRS, rozwiązanie w relacjach z nimi kwestii historycznych, przebudowa struktury Ministerstwa Spraw Zagranicznych, rozbudowa sieci dyplomatycznej w obszarze postsowieckim. Kolejne spory o politykę wschodnią miały się toczyć wokół tych określonych w pierwszym roku istnienia gabinetu Tadeusza Mazowieckiego problemów.

Czternaście miesięcy po artykule Friszkego ukazał się na łamach Tygodnika Solidarność znamienny tekst pióra Przemysława Żurawskiego vel Grajewskiego (7 września 1990 r.), niemal dokładnie wtedy, kiedy Krzysztof Skubiszewski zdecydował się złożyć ambasadorowi ZSRS w Polsce notę w sprawie wycofania wojsk sowieckich. Tekst młodego publicysty pokazywał przy okazji, jak trwały okazał się spór z ostatniego okresu przed 1989 r., toczony w podziemiu, którego istotą była diagnoza stanu rzeczy w Związku Sowieckim. Chodziło o to, czy z polskiego punktu widzenia można liczyć na zmianę charakteru polityki Rosji i w związku z tym wspierać w ZSRS siły skłonne do reform, czy też postawić wszystko na rozpad ZSRS. Zwraca uwagę duże poczucie sprawczości w polskich elitach, które były przekonane, że mają tak duży wpływ na procesy zmian i transformację w ZSRS.

Już w pierwszych miesiącach 1990 r. pojawiły się zarzuty, że rząd Tadeusza Mazowieckiego jest zbyt ostrożny wobec wydarzeń na sowieckiej Litwie. Mniej więcej rok po powstaniu gabinetu Mazowieckiego polityka wschodnia pierwszy raz w historii III Rzeczypospolitej stała się elementem wewnętrznej walki politycznej - w ówczesnym kontekście rywalizacji politycznej wewnątrz obozu 
solidarnościowego, którego stawką była wygrana w wyborach prezydenckich zaplanowanych na jesień $1990 \mathrm{r}$.

Przemysław Żurawski vel Grajewski nie pozostawiał wątpliwości co do intencji związanej z prowadzoną krytyką linii politycznej tandemu Mazowiecki-Skubiszewski. Nawiązania do toczącej się gorącej kampanii politycznej pomiędzy Lechem Wałęsą a Tadeuszem Mazowieckim były oczywiste. Jego artykuł może być zatem odczytywany w kontekście toczącej się już ostrej politycznej rywalizacji wewnątrz obozu „Solidarności”, ale też jako krytyka konkretnej linii w polityce zagranicznej. Już z pierwszych zdań artykułu wyłaniało się hasło przyspieszenia, które było centralnym motywem środowiska zwolenników Lecha Wałęsy, chociaż, rzecz jasna, po pierwsze odnoszącym się do innych dziedzin życia politycznego, przede wszystkim polityki wewnętrznej. W tym wypadku - w artykule zamieszczonym w Tygodniku Solidarność chodziło o przyspieszenie w procesie zrywania więzów z ZSRS.

Tekst Przemysława Żurawskiego vel Grajewskiego był podobnie ważny dla debaty na temat polityki wschodniej w III Rzeczypospolitej co artykuł Friszkego. Po pierwsze autor definiował od nowa główne osi dyskusji o problemach polityki wschodniej młodego państwa, a także proponował linię krytyki nowej ekipy z pozycji antysowieckich i antyimperialnych. Owe kwestie do dyskusji to: podejście do sprawy niepodległości Litwy, szerzej stosunek do rozpadu Związku Sowieckiego i szans na to, że na jego gruzach pojawią się demokratyczne państwa, a także sprawa zasadnicza: stosunek do wyprowadzenia wojsk sowieckich z Polski.

Ta druga kwestia słusznie traktowana była, co warto zaznaczyć, jako zagadnienie fundamentalne z punktu widzenia samego utrzymania się Polski jako niepodległego państwa. Warto $\mathrm{w}$ tym miejscu uczynić dwa zastrzeżenia: kwestia wyprowadzenia wojsk sowieckich z Polski, trybu i czasu, w jakim powinno się to dokonać, stała się jednym z tych tematów, które miały szczególnie duży potencjał, by wprowadzić zamieszanie do samego obozu „Solidarności”. Pozostaje oczywiście pytanie, na ile strona sowiecka własnymi kanałami wyolbrzymiała spór, który miał się toczyć jeszcze przez kilka lat.

\section{Debata o minimalizmie nad trumną Giedroycia (2000-2001)}

Tekst Bartłomieja Sienkiewicza pt. Pochwała minimalizmu z grudnia $2000 \mathrm{r}$. otwierał nowy rozdział w dyskusjach o polityce wschodniej III Rzeczypospolitej. Dnia 14 września 2000 r. zmarł Jerzy Giedroyc, a już kilka miesięcy po tym pojawił się artykuł polemiczny z jego linią. Charakterystyczna sprawa, że w głównym nurcie debaty o polityce wschodniej w obozie solidarnościowym 
za życia Giedroycia nie podejmowano z nim polemiki. Rozpoczęcie opisywanej dyskusji miało też jeszcze jeden walor: było swego rodzajem podsumowaniem pierwszej dekady polityki wschodniej III Rzeczypospolitej, dawało możliwość weryfikacji ewentualnych oczekiwań z pierwszych lat po $1989 \mathrm{r}$.

Teza Sienkiewicza była następująca: Polska nie ma możliwości wpływania na politykę na obszarze Międzymorza ${ }^{15}$ i ulega złudzeniom związanym z tempem i jakością transformacji u wschodnich sąsiadów. Konkluzja była klarowna, ale też kontrowersyjna: państwo polskie jest za słabe, aby prowadzić politykę, będąca próba zmiany przynależności cywilizacyjnej Międzymorza ${ }^{16}$. Jedynym państwem na Wschodzie, które zdaniem Bartłomieja Sienkiewicza mogłoby być partnerem Polski w zbudowaniu trwalszych więzów współpracy, była Litwa. Autorowi chodziło o to, że miała ona mniejszy od innych sąsiadów Polski na Wschodzie obszar, ale przede wszystkim Polskę z Litwą miało łączyć podobne postrzeganie sytuacji w Europie Środkowej i Wschodniej.

Tekst Sienkiewicza w pierwszej fazie wywołał polemikę ze strony Wojciecha Maziarskiego, która toczyła się częściowo na łamach Gazety Wyborczej, a częściowo na łamach Tygodnika Powszechnego. Wśród dyskutantów znaleźli się także Jerzy Pomianowski, Bohdan Cywiński, a nawet Czesław Miłosz. Szczególnie krótki acz krytyczny wobec Sienkiewicza głos Czesława Miłosza miał wielkie znaczenie - należał bowiem do najważniejszego żyjącego polskiego pisarza, noblisty i jednego z najważniejszych członków paryskiego środowiska Kultury.

Tekstem, który w precyzyjny i polemiczny sposób odpowiadał na postulat rewizji doktryny polityki wschodniej ukształtowanej w pierwszych dziesięciu latach istnienia III Rzeczypospolitej, był artykuł Bogumiły Berdychowskiej pt. Giedroyc nadal aktualny ${ }^{17}$. Podejście Berdychowskiej było następujące: polityka zagraniczna to inwestycja na lata, a ze strategicznego punktu widzenia bilans polskiej polityki wschodniej jest pozytywny. Bogumiła Berdychowska argumentowała, powołując się na polityczne autorytety Bohdana Osadczuka i Zbigniewa Brzezińskiego. Stawiała tezę przeciwną wobec podejścia Bartłomieja Sienkiewicza - wobec jego minimalizmu proponowała wręcz rozszerzenie agendy polskiej polityki wschodniej o wzmocnienie postulatu popierania ambicji europejskich Ukrainy.

15 B. Sienkiewicz (2000): Pochwała minimalizmu, Tygodnik Powszechny, 24-31 XII 2000, s. 12.

16 Ibid., s. 12.

17 B. Berdychowska (2001): Giedroyc nadal aktualny, Tygodnik Powszechny, 4 III 2001. 
Debata o minimalizmie toczona na łamach Tygodnika Powszechnego została skwitowana dyskusją w Fundacji im. Stefana Batorego 1 marca 2001 r. Spotkanie otworzył Krzysztof Kozłowski, który zapowiedział, że chciałby, żeby Polacy zaczęli się spierać $w$ tak dobry i pożyteczny sposób, jak dotychczasowi dyskutanci, $z$ tu obecnym sprawca catego zamieszania - Barttomiejem Sienkiewiczem ${ }^{18}$. W centrum uwagi postawił więc pierwszego krytyka Giedroycia wśród spadkobierców Giedroycia, czyli Bartłomieja Sienkiewicza. Aleksander Smolar zinterpretował poglądy Sienkiewicza jako przejaw kryzysu polskiej polityki wschodniej. Znamienne były słowa Smolara: $W$ jakimś sensie naśladowaliśmy $w$ stosunkach ze wschodnimi sasiadami role, jaka często naiwnie przypisywaliśmy Niemcom w naszych stosunkach $z$ NATO, a zwłaszcza z Unia Europejska. I rzeczywiście polscy politycy próbowali odgrywać rolę rzecznika naszych sąsiadów na różnych spotkaniach międzynarodowych, podkreślając wagę w polityce europejskiej takich krajów jak Ukraina. Ten okres zdaje się kończyćc ${ }^{19}$.

Zdzisław Najder umieszczał myśl Giedroycia w tradycji piłsudczykowsko-prometejskiej: Niejako unosi się nad nami duch Jerzego Giedroycia. Ale nad tym duchem unosi się inny: Józefa Pitsudskiego. Myśl „Kultury” była przedłużeniem jego koncepcji i Pan Jerzy tego nigdy nie ukrywat. Sądzę, że ta myśl nie zostataby tak dobrze przyjęta, gdyby nie byta kontynuacja pewnej tradycji prometejskiej. A skoro przypominam nazwisko Pitsudskiego, to przywołam jeszcze przydomek, jakim go opisywano - byt to "romantyczny realista”, tzn. stawiat sobie romantyczne cele, ale przygladat się temu, jakimi instrumentami rozporzadza, i starat się je wzbogacać $w$ najrozmaitsze sposoby: od wspótpracy $z$ wywiadem austriackim $i$ japońskim po stynna biesiadę z polskimi monarchistami po zamachu majowym ${ }^{20}$. Po takim ustawieniu sprawy podejmował obronę argumentów Bartłomieja Sienkiewicza, interpretując je nie jako zerwanie z tradycją giedroyciowską (co zdaniem Najdera zarzucała Sienkiewiczowi Bogumiła Berdychowska), ale raczej jako sprowadzenie jej do kategorii realistycznych.

Jerzy Marek Nowakowski występował w dyskusji z zawoalowaną krytyką Sienkiewicza. Ciekawy był głos Dariusza Rosatiego, byłego już wówczas ministra spraw zagranicznych, który z jednej strony wprost odwoływał się do doktryny Giedroycia-Mieroszewskiego, z drugiej jednak wskazywał na jej dezaktualizację i przyszłość polskiej polityki wschodniej widział już przede wszystkim

18 Polska Polityka Wschodnia. Pełny zapis dyskusji zorganizowanej przez Fundację im. Stefana Batorego oraz redakcję Tygodnika Powszechnego w dniu 1 marca 2001 r., op. Grażyna Czubek, Piotr Kosiewski, http://www.batory.org.pl/ftp/program/forum/ ppw.pdf (dostęp 21 grudnia 2018 r.), s. 1.

19 Ibid., s. 2.

20 Ibid., s. 6. 
w kontekście europejskim: Polska musi jednak wyjść niejako poza tę doktrynę $i$ zaoferować alternatywa droge rozwoju, która musi być zwiąana $z$ propozycja. europejska - nie może być to polska, autorska oferta ${ }^{21}$.

Bartłomiej Sienkiewicz podjął linię obrony własnego stanowiska poddaną mu przez Najdera i w pewnym sensie Smolara: Idee sa tak dtugo żywe, póki się o nich dyskutuje. Jakakolwiek próba stworzenia kanonu myślenia Giedroycia i Mieroszewskiego, zamknięcia do szklanej gablotki i stwierdzenia, że świętokradztwem jest próba jej otworzenia, jest dla mnie metodą nie do zaakceptowania. Mój szacunek wobec dzieła paryskiej „Kultury” raczej nakazuje caty czas dopasowywanie tego, co zostato napisane kilkadziesiąt lat wcześniej, do tego, co się dzieje w tej chwili. Bo tylko w ten sposób jesteśmy w stanie utrzymać tę ideę przy życiu² ${ }^{22}$.

W dyskusji zabrali głos: Jerzy Kłoczowski, Wojciech Maziarski, Tadeusz Olszański, Jerzy Regulski, Tadeusz Chabiera, Jacek Cichocki, Leszek Moczulski, Kazimierz Wóycicki i Mariusz Jan Radło. Z kilkumiesięcznej dyskusji publicystycznej i jej podsumowania na początku marca 2001 r. w Fundacji im. Stefana Batorego wynikało szereg istotnych wniosków. Bartłomiej Sienkiewicz sprowokował spór, który doprowadził do pierwszej próby redefinicji rozumienia linii giedroyciowskiej w III Rzeczypospolitej, a główne argumenty stron sporu ustaliły się w polemice Sienkiewicz-Berdychowska. Są też oczywiste wnioski znacznie szerszego znaczenia: po dekadzie polskiej polityki wschodniej zaprogramowanej w latach 1989-1991 pojawiła się w elitach kształtujących tę politykę potrzeba jej podsumowania, która przybrała formę dyskusji nad dziedzictwem Giedroycia - charakterystyczne, jak zróżnicowane politycznie grono zdecydowało się w tej debacie uczestniczyć.

\section{Rosja jako wyzwanie (2008-2009)}

Dnia 19 lutego 2008 r. na łamach Tygodnika Powszechnego ukazał się artykuł Andrzeja Brzezieckiego pt. Koniec świata romantyków. W pewnym stopniu tekst nawiązywał do Pochwały minimalizmu Sienkiewicza sprzed prawie ośmiu lat. Nawiązania były oczywiste: do skojarzeń skłaniało miejsce debaty (Tygodnik Powszechny) i jej główne tezy. To, co było w debacie zapoczątkowanej przez Brzezieckiego nowego, to fakt, że włączała się do niej nowa generacja badaczy i znawców Wschodu (polemika pomiędzy Andrzejem Brzezieckim i Pawłem Kowalem).

\footnotetext{
21 Ibid., s. 15-16.

22 Ibid., s. 21.
} 
Druga kwestia była zasadnicza: kontekst wewnątrzpolityczny sytuacji w Polsce po wyborach przegranych przez PiS oraz relacje polsko-ukraińskie. W okresie po debacie $\mathrm{z}$ lat 2000-2001 przeszły one kilka faz, $\mathrm{w}$ tym wsparcie przez Polskę aspiracji ukraińskich środowisk niezależnych w czasie Pomarańczowej Rewolucji w latach 2004/2005, intensywne relacje w okresie porewolucyjnym i ich pewne załamanie na przełomie 2007 i 2008 r. Wbrew oczekiwaniom nie doszło wówczas do wizyty nowego premiera Polski na Ukrainie, ale do wizyty Donalda Tuska w Moskwie. Tym razem zatem także polemiki wokół polskiej polityki wschodniej związane były z toczonymi akuratnie sporami politycznymi, chociaż $\mathrm{w}$ oczywisty sposób nie ograniczały się tylko do nich. Andrzej Brzeziecki napisał tekst po udziale przedstawicieli Polski z prezydentem Aleksandrem Kwaśniewskim na czele w rozwiązaniu konfliktu politycznego na Ukrainie w 2005 r. oraz kilku latach istotnego zaangażowania Lecha Kaczyńskiego na polu polityki wschodniej, w tym szczególnie w relacje polsko-litewskie, polsko-ukraińskie i polsko-gruzińskie.

Polityka Lecha Kaczyńskiego była przedmiotem krytyki opozycji w okresie kampanii wyborczej w 2007 r. Zarzucano jej nieefektywność. Polemiki polityczne wokół linii polityki wschodniej prezydenta Lecha Kaczyńskiego były bardzo zacięte. Sam Lech Kaczyński definiowal się niekiedy jako kontynuator linii politycznej Jerzego Giedroycia. W 2007 r. podczas wręczenia nagrody im. Jerzego Giedroycia Bohdanowi Osadczukowi prezydent RP mówił tak na Zamku Królewskim w Warszawie: Jesteśmy też niewątpliwie rzecznikiem ukraińskiej sprawy w Europie. Jesteśmy i mam nadzieję, że pozostaniemy. To samo zreszta dotyczy krajów leżacych jeszcze dalej na wschód, o czym przed chwila powiedziatem. Na wschód od Polski, choć pótnocny, leży także Republika Litewska i inne dwa pozostałe kraje bałtyckie. Mogępowiedzieć, że w ciagu ostatnich dwóch lat, choć zdarzało się, że pojawialy się trudności, zdołaliśmy nawiąać bardzo bliskie stosunki w szczególności z Litwa i Panem Prezydentem Adamkusem. Można powiedzieć, że $w$ tym zakresie to, o czym pisat i mówit Pan od wielu lat, to, co jest testamentem naczelnego twórcy i naczelnego redaktora "Kultury”, jest w miarę dzisiejszej sytuacji geopolitycznej realizowane. Jest realizowane dziś, kiedy te sprawy, te kierunki polityki wydaja nam się oczywiste ${ }^{23}$. Jednak działania Lecha Kaczyńskiego w polityce wschodniej były krytykowane przez przeciwny obóz polityczny. Z tego punktu widzenia pierwsze ruchy gabinetu Donalda Tuska w polityce zagranicznej w warunkach kohabitacji wzbudzały szczególnie gwałtowne spory.

${ }^{23}$ Lech Kaczyński, Realizowany jest testament Giedroycia, 8 listopada 2007, prezydent.pl, http://www.prezydent.pl/archiwum-lecha-kaczynskiego/aktualnosci/rok-2007/ art,149,963,realizowany-jest-testament-giedroycia.html (dostęp 19 października 2018 r.). 
Data ukazania się artykułu Andrzeja Brzezieckiego nie była więc przypadkowa. Jego tekst ukazał się po wspomnianej już wizycie nowego premiera Donalda Tuska w Moskwie. Główna myśl artykułu krążyła wokół zakwestionowania efektywności dotychczasowej polityki wschodniej prowadzonej w oparciu o doktrynę Giedroycia i poszukiwania możliwości porozumienia się z Rosją. Artykuł Brzezickiego otworzył kolejny rozdział dyskusji o polskiej polityce wschodniej. Wiosenna dyskusja w $2008 \mathrm{r}$. toczyła się przed wydarzeniami, które miały w ogromnym stopniu wpłynąć na polską, ale także europejską, politykę wschodnią. Dalsza część rozpoczętej dyskusji prowadzona była jesienią i toczyła się już po bardzo ważnych z punktu widzenia polityki wschodniej wydarzeniach, a mianowicie po szczycie NATO w Bukareszcie oraz wojnie gruzińsko-rosyjskiej z sierpnia $2008 \mathrm{r}$. Z interesującego nas punktu widzenia istotą szczytu bukareszteńskiego była kwestia przyznania Gruzji i Ukrainie Planu działań na rzecz członkostwa w NATO (MAP - ang. Membership Action Plan). Wspólna akcja dyplomatyczna Polski i kilku państw członkowskich wsparta wewnątrz sojuszu przez USA, a także częściowo przez Niemcy, nie dała oczekiwanego efektu. Niepowodzenie szczytu zwiększyło zagrożenie wywoływanymi przez Rosję incydentami i prowokacjami na pograniczu z Gruzją. Wszystko to zaś trafiło na okres wyjątkowo w dziejach relacji polsko-gruzińskich intensywnych kontaktów politycznych i w innych dziedzinach.

W kontekście wojny jednym z najważniejszych wydarzeń było wystąpienie Lecha Kaczyńskiego w Tbilisi 12 sierpnia 2008 r. Lech Kaczyński udał się do Gruzji w obliczu następującej inwazji rosyjskiej w towarzystwie przywódców państw regionu: Ukrainy, Litwy, Łotwy i Estonii. Przemowa prezydenta Rzeczypospolitej do zgromadzonych tłumów na placu w Tbilisi ujmowała istotę polskiego przesłania ideowego w polityce wschodniej: powiązanie kwestii wolności i niepodległości Polski i państw regionu oraz przesłanie wsparcia państw zagrożonych rosyjskim imperializmem. Wpisywała się zatem w oczywisty sposób w kontekst prometejski. Wydarzenia na Kaukazie Południowym przyspieszyły powstanie w Unii Europejskiej Partnerstwa Wschodniego - dostarczyły bowiem zwolennikom prowadzenia aktywnej polityki UE na Wschodzie poważnych argumentów.

$\mathrm{Z}$ drugiej strony reakcja Unii Europejskiej na wydarzenia na Kaukazie, czyli pierwsze tak demonstracyjne naruszenie ustalonych po II wojnie światowej granic i zasad prawa międzynarodowego w Europie, była krótkotrwała. Tekst Piotra Skwiecińskiego pt. Kompleks Rosji przenosił debatę o polskiej polityce wschodniej z rozważania nad sposobami wsparcia transformacji u najbliższych sąsiadów na relacje polsko-rosyjskie, które były wtedy szeroko dyskutowane. Tytuł nadany tekstowi nawiązywał w oczywisty sposób do artykułu Mieroszewskiego, podobnie jak treść, czyli założenie, że kluczem do polityki w regionie 
są relacje polsko-rosyjskie. Tezy Piotra Skwiecińskiego napisane zaledwie kilka tygodni po inwazji Rosji na Gruzję brzmiały prowokacyjnie: publicysta opierał się na tezie, że Polacy nie są w stanie zaakceptować dominacji Rosji w regionie i żyją wspomnieniami i sentymentami za historyczną rolą Polski, która minęła.

W omawianym okresie przedstawiciele polskiej dyplomacji stawiali na dwa kluczowe elementy w polityce wschodniej: powstanie Partnerstwa Wschodniego jako sposobu na brukselizację polskiej polityki wschodniej oraz poprawę relacji polsko-rosyjskich. Debata o polityce wschodniej lat 2008-2009 toczyła się z udziałem ministra sprawa zagranicznych Radosława Sikorskiego, który zabierał w niej głos zarówno publikując teksty o charakterze publicystycznym czy programowym, jak i udzielając wywiadów. Najważniejszy z tekstów Sikorskiego ukazal się 1 września 2009 r. pt. Lekcje historii, modernizacja i integracja. Kontekst polityczny artykułu nie był skrywany: ukazał się on w rocznicę wybuchu II wojny światowej, w czasie gdy w związanych z tym uroczystościach uczestniczyć miał Władimir Putin.

Radosław Sikorski sygnował tekst, który wprowadzał do debaty o polityce zagranicznej Polski figurę polityki piastowskiej. Było jasne, że oznacza to zarówno określony zespół poglądów na politykę wobec Niemiec, jak i na politykę wschodnią. W odniesieniu do Niemiec miało oznaczać zbliżenie na wzór relacji Bolesława Chrobrego z cesarzem Ottonem III. Deklarowanie realizacji programu piastowskiego niejako w opozycji do prezydenta Lecha Kaczyńskiego, który w domyśle prowadził politykę jagiellońską, mogło być także odczytywane jako sygnał do Rosji, że Polska obniża poziom swojego zainteresowania polityką wschodnią w sferze pomiędzy Polską a Rosją. Interpretacji figury zaproponowanej przez urzędującego szefa dyplomacji mogło być wiele. Nic zatem dziwnego, że rzucona przez Sikorskiego, a prawdopodobnie wypracowana wcześniej w MSZ w kręgu jego współpracowników, idea wywołała dyskusję, która koncentrowała się przez jakiś czas na eksploatowaniu zaproponowanej dychotomii polska piastowska - polska jagiellońska ze wszystkimi tego konsekwencjami. Dyskusje na temat polityki wschodniej gabinetu PO-PSL w pierwszych latach po jego sformowaniu były jednym $\mathrm{z}$ kilku pól ostrych polemik politycznych w dużym stopniu związanych $\mathrm{z}$ aktualną sytuacją wewnętrzną w kraju. Przerwała je dopiero katastrofa smoleńska 10 kwietnia 2010 r.

\section{Wieczna debata o Giedroyciu (2010)}

Dnia 17 maja 2010 r. w Ośrodku Studiów Wschodnich (OSW) odbyła się dyskusja na temat Koniec epoki Giedroycia?; zapowiadała ona kolejną odsłonę dyskusji o polskiej polityce wschodniej, dla której jeszcze raz wstępem była refleksja 
na temat aktualności linii politycznej Kultury. Dnia 29 maja 2010 r. na łamach Rzeczpospolitej ukazał się artykuł Pożegnanie z Giedroyciem Bartłomieja Sienkiewicza - nasuwały się skojarzenia z dyskusją z 2001 r. Także główna teza Sienkiewicza nie zaskakiwała. Już w pierwszym zdaniu pisał on: Giedroyciowsko-pitsudczykowska koncepcja polityki wschodniej poniosta klęskę. Bartłomiej Sienkiewicz występował w kolejnej już odsłonie dyskusji na temat spuścizny ideowej Jerzego Giedroycia niemalże jako klasyk jego krytyki. Przedstawiał skutki polskiej polityki wschodniej jako katastrofalne. Sienkiewicz proponował obniżenie napięcia w relacjach z Rosją, a jednocześnie próbę odzyskania pola w grze politycznej w skali europejskiej dzięki aktywności na polu polityki wschodniej Unii Europejskiej.

Kontekst artykułu Sienkiewicza był ważny ze względu na bliskość czasową do katastrofy smoleńskiej. Bezpośrednio po katastrofie linia rządu poszukiwania porozumienia z Rosją nie tylko była kontynuowana, ale wręcz niejako uległa wzmocnieniu. Na fali emocji związanych głównie z reakcją społeczeństwa rosyjskiego na tragedię między innymi w środowisku OSW i instytucji analitycznych związanych z administracją pojawiła się idea, że możliwa jest w miarę szybka poprawa relacji polsko-rosyjskich. Oczywiście jeśli chodzi o polityków, tego rodzaju nadzieje zależały od oceny reakcji Rosji na katastrofę i wręcz oceny przyczyn wypadku.

Idea porozumienia z Rosjanami pojawiła się co prawda w wyborczym wystąpieniu Jarosława Kaczyńskiego jako kandydata na prezydenta - jednak generalnie Prawo i Sprawiedliwość (PiS) i związane z tą partią środowiska odrzuciły tego rodzaju pomysł. Na poziomie czynników rządowych nadzieja ta była wyrażana w bardziej jednoznaczny sposób, na poziomie eksperckim w niesłychanie umiarkowany. Wyrazicielem tego podejścia może być Marek Menkiszak, czołowy ekspert OSW ds. rosyjskich, który w wywiadzie z 25 maja 2010 r. tak wyjaśniał sens posmoleńskiej polityki wobec Rosji, którą przez kilkanaście tygodni prowadził gabinet Donalda Tuska: Oczywiście, atmosfera polsko-rosyjskich relacji bardzo się poprawita. Miała na to wpływ postawa rosyjskiej opinii publicznej, a przede wszystkim władz, wobec tragedii smoleńskiej, jak i $w$ bolesnych dla nas kwestiach historycznych. Ta empatyczna reakcja została $w$ Polsce doceniona, jednak jakie będa tego konsekwencje, zależy od dalszych dziatań obu państw ${ }^{24}$.

Dyskusja otwarta tekstem Bartłomieja Sienkiewicza z 29 maja 2010 r. wywołała kolejne wypowiedzi: Pawła Kowala, Andrzeja Halickiego, a także Antoniego Z. Kamińskiego i Henryka Szlajfera. W artykule Kamińskiego

${ }^{24}$ Nie możemy żyć na cmentarzach, Wirtualna Polska, 25 maja 2010 https://wiado mosci.wp.pl/nie-mozemy-zyc-na-cmentarzach-6082129691739265a (dostęp 17 grudnia 2018 r.). 
i Szlajfera pojawiła się próba wyzwolenia dyskusji z historycznego kostiumu narzuconego głośnym artykułem Sikorskiego z września 2009 r. Dwaj profesorowie podkreślali, że operowanie pojęciami polityka jagiellońska czy polityka piastowska odnosi się do nieaktualnych okoliczności politycznych, i postulowali, by politykę wschodnią i regionalną Polski rozpatrywać przede wszystkim w kontekście europejskim i transatlantyckim (Takie spojrzenie na „pożegnanie” Bartłomieja Sienkiewicza z koncepcja Giedroycia-Mieroszewskiego - przepraszamy: "giedroyciowskim kostiumem polityki wschodniej" - ujawnia w całej petni bezsens jego stanowiska. Urojeniem jest te $\dot{z}$ „jagiellonizm” w wydaniu Pawła Kowala).

Na zaznaczenie zasługuje jeszcze jeden tekst polemiczny wobec tekstów Bartłomieja Sienkiewicza, a mianowicie artykuł Bogumily Berdychowskiej i Henryka Wujca pt. Idee spuszczone ze smyczy. Autorzy tak diagnozowali istotę sporu z Sienkiewiczem: w jego propozycjach widzieli pomysł na dążenie do powstania na wschód od granic Polski strefy buforowej, a sami przeciwstawiali temu ideę rozszerzania instytucji zachodnich na wschód, po to by wzmocnić stabilność sąsiadów, szczególnie Ukrainy, co w ich ujęciu było najważniejszym interesem politycznym Polski.

Dnia 14 września 2010 r., w Sali Balowej Pałacu Potockich Uniwersytetu Warszawskiego (UW) na zaproszenie Studium Europy Wschodniej UW odbyła się dyskusja nt. Stan, kierunki i potrzeby polskiej polityki wschodniej, prowadzona przez Jana Malickiego. Formalnie nie była ona podsumowaniem toczonej w poprzednich dwóch latach publicznej dyskusji, jednak faktycznie można ją za taką uznać. Uczestniczący w dyskusji wiceminister Henryk Litwin rozpoczął od szczegółowego omówienia stanu polityki wschodniej, wybijając elementy, które uznał za sukcesy kolacji rządowej Platformy Obywatelskiej i Polskiego Stronnictwa Ludowego, jednak, co było charakterystyczne, podkreślał, że gotów jest słuchać krytycznych głosów ${ }^{25}$.

Bartłomiej Sienkiewicz podkreślał swego rodzaju nieadekwatność myśli Jerzego Giedroycia w stosunku do polityki wschodniej Polski w latach 20002010 ze względu na fakt, że toczyła się ona w kontekście polityki europejskiej ${ }^{26}$. Warto zatem przypomnieć, że centralnym zagadnieniem polityki wschodniej dyskutowanym po 2008 r. w kontekście unijnym było Partnerstwo Wschodnie - kwestię dyskusji na temat inspiracji polską myślą polityczną w powstaniu Partnerstwa Wschodniego traktuję jako odrębne zagadnienie.

W debacie na Uniwersytecie Warszawskim pojawiało się wiele wątków obecnych już wcześniej w debacie publicystycznej. Niektóre kwestie wymagają

${ }^{25}$ Zapis dyskusji „Stan, kierunki i potrzeby polskiej polityki wschodniej”, Nowy Prometeusz, nr 0/2010, s. 46.

${ }^{26}$ Ibid., s. 49. 
jednak podkreślenia. W dyskusji mocno zaznaczył się wątek krytyki Radosława Sikorskiego przez Bartłomieja Sienkiewicza za wprowadzenie do dyskusji o polityce wschodniej kategorii polityki piastowskiej i polityki jagiellońskiej. Zresztą w szerszym ujęciu debata o polskiej polityce wschodniej z 2010 r. charakteryzowała się szczególnie silną obecnością figur i metafor historycznych. Z dużym natomiast sceptycyzmem lub krytyką m.in. ze strony Bogumiły Berdychowskiej i Andrzeja Ananicza spotkała się zaprezentowana przez Bartłomieja Sienkiewicza idea pauzy strategicznej w relacjach ze wschodnimi sąsiadami ${ }^{27}$.

\section{Co po Giedroyciu? (2015-2017)}

Włączony do wyboru tekstów źródłowych tekst Andrzeja Brzezieckiego pt. Idee $w$ działaniu z 2013 r. można odczytywać jako częściową rezygnację z krytyki myśli Jerzego Giedroycia przedstawioną, także na łamach Tygodnika Powszechnego, na samym początku 2008 r. Był to już czas, gdy jasne było, że próby porozumienia $z$ Rosją podejmowane po wyborach w 2007 r. i zakończone definitywnie w drugiej połowie $2010 \mathrm{r}$. nie przyniosą efektu, a wartością polskiej polityki wschodniej jest stałość w polityce zagranicznej.

Jednak kolejna dyskusja o aktualności doktryny Giedroycia rozgorzała po dojściu do władzy PiS w 2015 r. Tym razem jedną z osób, które opowiedziały się za trwaniem przy tradycji Giedroyciowskiej, był Bartłomiej Sienkiewicz ${ }^{28}$. Dla debaty o dziedzictwie Giedroycia charakterystyczne są artykuły Wojciecha Konończuka pt. Czas na doktrynę postgiedroyciowska wobec Ukrainy, obszerny tekst Katarzyny Pełczyńskiej-Nałęcz ze stycznia 2017 r. pt. Pożegnanie z Giedroyciem oraz artykuł Wojciecha Jakóbika Nie rezygnujmy z Giedroycia!

Zapalnikiem ostatniej, niemalże trwającej na naszych oczach, dyskusji o dziedzictwie Giedroycia był artykuł Wojciecha Konończuka, a głównym miejscem debaty - Nowa Europa Wschodnia. To jednak, co okazało się nowe w najświeższych dyskusjach o Giedroyciu, to płynące ze środowisk nacjonalistycznej prawicy głosy całkowitego zakwestionowania tej myśli i giedroyciowskiej tradycji. Dotąd bowiem w III Rzeczypospolitej nawet krytyka tej tradycji myślenia - jak w klasycznym tekście Sienkiewicza z 2000 r. czy aktualnym Konończuka - nie polegała przecież na zakwestionowaniu tego nurtu co do zasady, ale na uznaniu, że był użyteczną formułą prowadzenia polityki wschodniej w jakimś okresie, następnie zaś w wyniku zmiany okoliczności politycznych ulegał dezaktualizacji. Dotychczasowa formuła dyskusji o doktrynie Giedroycia w III RP

27 Ibid., s. 58-59, 62, 71.

${ }^{28}$ Czas bić na alarm - rozmowa z P. Kowalem i B. Sienkiewiczem, NEW, s. 9. 
zasadzała się na apriorycznej niemal akceptacji Giedroycia. Tymczasem po 2015 r. do głosu doszło podejście polegające na kwestionowaniu użyteczności myśli Giedroycia co do zasady od samego początku.

Obrona dorobku Giedroycia w tym wypadku po pierwsze oznacza polemizowanie z poglądami nacjonalistycznymi w szerszym ujęciu, po drugie oznacza, że obrońcami dawnego lokatora z Maisons Laffitte stają się także ci, którzy dowodzili już wcześniej dezaktualizacji jego myśli, jak Sienkiewicz. Najważniejsze jednak, że aktualna obrona Jerzego Giedroycia musi w związku z nowym kontekstem dyskusji proponować nieco inną argumentację, co dobitnie wyraził Wojciech Jakóbik, dowodzący realizmu podejścia Giedroycia do polityki wschodniej (Idea Giedroycia nie jest romantyczna). Warto zauważyć, że po kilkunastu latach w dyskusji o recepcji myśli politycznej Kultury wróciła argumentacja, która zbudowana została tuż po śmierci redaktora w kontekście dyskusji o polskiej polityce wschodniej toczonej w latach 2000-2001.

\section{Podsumowanie}

Przegląd najważniejszych tekstów publicystycznych na temat polskiej polityki wschodniej zaskakuje żywotnością linii politycznej sformowanej przez Giedroycia i Mieroszewskiego oraz powstałej w oparciu o nią w czasach III Rzeczypospolitej doktryny Giedroycia, które są niemal stałym elementem dyskusji intelektualnej nad problematyką polskiej polityki wschodniej w III RP. Żadna inna idea nie zyskała takiego zainteresowania i nie była chociażby podobnie długo dyskutowana. Kilka pokoleń badaczy, ekspertów i polityków prowadzi w gruncie rzeczy nieustanny spór o polską politykę wschodnią, który charakteryzuje się kilkoma niezmiennymi elementami: odniesieniami do myśli Kultury (najczęściej zresztą bez precyzyjnego jej dookreślania), podobnym, ale nie sprecyzowanym pojęciem polskiej polityki wschodniej i odniesieniami do aktualnej sytuacji politycznej.

To właśnie konkretne polityczne warunki w Polsce oraz sytuacja międzynarodowa dyktowały $\mathrm{w}$ toku prowadzonej dyskusji ustawienie głównych osi sporu. W debacie toczonej po roku od powstania gabinetu Tadeusza Mazowieckiego była to sprawa tempa i formy wyprowadzenia wojsk sowieckich z Polski oraz stosunku do rozpadu ZSRS. Dyskusja z lat 2000-2001 była pierwszą próbą rozrachunku zarówno z doktryną Giedroycia na poziomie teoretycznym, jak i próbą wyciągania wniosków z pierwszej dekady polityki wschodniej III Rzeczypospolitej. Kolejna debata, której nasilenie przypadło na lata 2008-2009 dotyczyła w większym stopniu szans na poprawę relacji z Rosją i oceny neoprometejskiej polityki Polski na Wschodzie w latach 2004-2007. Debata toczona 
w cieniu katastrofy smoleńskiej w roku 2010 oparta była na nadziejach na porozumienie z Rosją w obliczu tej katastrofy.

Dyskusje na temat aktualności dziedzictwa Jerzego Giedroycia stały się też jedną z głównych osi sporów toczonych w późniejszym okresie wśród pokolenia najmłodszych badaczy i ekspertów - w tym jednak wypadku związane były także z zakwestionowaniem w debacie publicznej propozycji Giedroycia i linii politycznej kolejnych rządów III Rzeczypospolitej. 